\title{
Research on the Development of Youth E-Commerce in Jilin Province Against the Background of Rural Revitalization Strategy
}

\author{
Lihong Zhao \\ Jilin Engineering Normal University \\ Changchun, China 130031
}

\author{
Tongyang Han \\ Jilin Engineering Normal University \\ Changchun, China 130031
}

\begin{abstract}
Youth is the future of the country and the hope of the nation. Under the background of rural revitalization strategy, this paper analyzes the current situation of youth ecommerce development in Jilin Province, puts forward the predicament faced by youth e-commerce in Jilin Province, and then proposes countermeasures for the development of youth e-commerce in Jilin Province.
\end{abstract}

Keywords—youth; e-commerce; Jilin Province

\section{INTRODUCTION}

Youth is the future of the country and the hope of the nation. When youth is young, the nation is prosperous, while young people are strong and the country is strong. Promoting young people to grow better and develop faster is the basic and strategic project of the country. According to the relevant policies and regulations of the party and the state, according to the overall goals and requirements of economic and social development, the youth has become the main body and the main driving force. Supporting urban and rural youth to participate in e-commerce is an important channel to promote youth entrepreneurship, especially to help rural youth increase their incomes. It is also a concrete measure for the Communist Youth League to participate in the central strategic plan for poverty alleviation.

\section{Proposal of RuRAL ReVitalization StRATEGy}

On February 4, 2018, the Central Committee of the Communist Party of China promulgated the 2018 Central Committee Document "Opinions of the CPC Central Committee and the State Council on Implementing the Rural Revitalization Strategy." On March 5, 2018, Premier Li Keqiang of the State Council raised the agricultural and rural work into a national strategy for the first time in his government work report, proposing a strategic deployment of rural revitalization. Therefore, further support for young ecommerce, solve their practical difficulties in development, and have positive significance for the implementation of the rural revitalization strategy.

\section{DEVElopMEnt Status OF Youth E-COMMERCE IN JILIN PROVINCE}

In the first quarter of 2019, the amount of e-commerce transactions in Jilin Province reached 179.5 billion yuan, ranking 20th in the country, with a growth rate higher than 19 percentage points nationwide. Among them, the province's online retail sales increased by $20.7 \%$ year-onyear, and the growth rate was 5.9 percentage points higher than the national level. From the category, bulk and B2B transactions mainly include Chinese medicinal materials such as ginseng and velvet antler, food and beverage, etc., which drive the e-commerce transaction volume to be stable; physical-type online retailing mainly focuses on food health care, clothing and shoes, and maternal and child products. Jilin rice, Songyuan black corn, Gongzhuling corn oil and other regional brands on the line Alibaba Taoxiang sweet sought after, Changchun City's ginseng, American ginseng, bean bags, Jilin City pine nuts, black fungus, roasted cold noodles and other food and shoes, white The city's baby food, northeastern miso, and Drink of Tao $\mathrm{Er} \mathrm{He}$ have become hot products. At the same time, the online supply of service-oriented businesses such as catering, tourism, leisure and entertainment continued to expand, driving the retail sales of service-oriented networks to increase by $18.2 \%$ yearon-year, 1.8 percentage points higher than the national level.

Meihekou city has 19 townships and 303 natural villages in the city, and has fully covered e-commerce service stations. Through e-commerce, the number of entrepreneurs and employment reached 2,300, driving 150 households to increase their annual income by 2 million yuan. In 2018, the total retail sales of e-commerce reached 3.8 billion yuan, and the rural e-commerce transaction volume reached 2.6 billion yuan. The development of e-commerce industry is in the forefront of Jilin Province. Meihekou City E-commerce Industrial Park and Lishui Meihekou E-commerce Industry Cooperation Demonstration Park covers a total area of 16,000 square meters. The Lishui E-commerce Company is responsible for the planning, design, decoration, investment and follow-up operations of the entire park. At present, there are more than 30 e-commerce companies that have entered the park, and more than 500 products from the OTO 
Experience Center have been collected, and 26 entrepreneurial practitioners have been recruited.

On May 20, 2015, Changchun E-Commerce Association Incubation Base and Changchun Huishang E-commerce Pioneer Park were officially launched, and Changchun "Happy Buy" e-commerce platform was also launched simultaneously. The Changchun E-Commerce Association Incubation Base provides mature one-stop integrated training, management consulting, technical support and other supporting services to small and micro enterprises interested in the development of the Internet economy to promote the development of the real economy to the Internet; Changchun City E-Commerce Pioneer Park can provide online trading and offline experience service platform for small and microe-commerce companies in Changchun through professional entrepreneurship projects, and provide entrepreneurial platforms for college students and entrepreneurs; Changchun "Happy Buy" website is dedicated to build a comprehensive e-commerce platform based in Changchun City, it has integrated 200,000 items from more than 1,000 suppliers and launched the "Internet + Community" service project. The citizens received the goods within 6 hours of the order. In the first half of 2019, the transaction volume of the e-commerce platform in Changchun City was 3.07 billion yuan for the unit (B2B+B2G), accounting for $79.7 \%$ of the total transaction volume, up $74.2 \%$ year-on-year; for individuals $(\mathrm{B} 2 \mathrm{C}+\mathrm{C} 2 \mathrm{C})$ The transaction volume was 780 million yuan, accounting for $20.3 \%$ of the total transaction volume, a yearon-year increase of $0.2 \%$. The transaction volume of the Changchun e-commerce platform to the unit $(B 2 B+B 2 G)$ has grown rapidly, but the proportion of the total transaction volume is too large, indicating that the Changchun ecommerce platform is too dependent on the transaction of the unit $(\mathrm{B} 2 \mathrm{~B}+\mathrm{B} 2 \mathrm{G})$, and it is currently hot in the country. The $\mathrm{B} 2 \mathrm{C}$ market is in stark contrast.

On October 26-27, 2018, at the "6th China Taobao Village Summit Forum" hosted by Alibaba Group, Wangjia Village, Chaihe Town, Dianshi City, Jilin City and Dayandi Village, Gudiandian Town, Changyi District were awarded. The title of "China Taobao Village" is the two villages that were awarded the title of "China Taobao Village" after being named "China Taobao Village" in Qipan Village, Longtan District, Jilin City last year, and Huangshaodian Village, Luohe City. So far, there are 4 "China Taobao Villages" in Jilin City, accounting for $30 \%$ of the total number of "China Taobao Villages" in the three northeastern provinces. All four "China Taobao Villages" in Jilin Province are produced in Jilin City. Because the "Taobao Village" certification standard is very strict, and based on Alibaba Group's backend big data, it is reviewed by e-commerce experts. The "China Taobao Village" title is very high in gold content, which is the level of county e-commerce economic development. In the past two years, the four "Taobao Villages" in Jilin City have realized total network sales of 160 million yuan, directly increasing the economic income of farmers by more than 30 million yuan, and receiving more than 7,200 person-times of training, creating nearly 1,000 jobs. During the online cargo festival from June 1st to 18th, 2018, Huangsongdian sold more than 60,000 orders online, and its sales exceeded 3 million yuan. The "Sen Baiwei" and other e-commerce brands enjoy high reputation in the province and even the whole country. In 2016, Jilin City achieved an online retail transaction volume of 12.638 billion yuan, a year-on-year increase of 56.8\%. In 2017, the online retail transaction volume reached 18.957 billion yuan, a year-on-year increase of $50 \%$. In the first three quarters of 2018, the online retail transaction volume reached 17.15 billion yuan, an increase of $42.5 \%$ over the same period last year. The geographical development of youth e-commerce in Jilin Province is uneven. The proportion of young ecommerce entrepreneurs in urban areas is more than three times that of rural youth e-commerce entrepreneurs. The proportion of urban youth e-commerce entrepreneurs is $77.93 \%$, while rural youth e-commerce entrepreneurs .The proportion is only $22.07 \%$. The rural youth e-commerce training project demonstration training class (Jilin Province), sponsored by the Central Youth Work Department of the Central Committee of the Communist Youth League and hosted by the Huinan Youth League Committee of the Communist Youth League, officially started from 36 counties (cities, districts) of 9 cities (states) in the province. More than 90 outstanding e-commerce youth representatives participated in the training. The training invited 4 experts from Changchun Wanhe, Beijing Taobao University and Qihe Agriculture to give lectures for a period of 5 days. On the central "three rural" policy and "Internet +" policy, the development trend and basic operation of e-commerce and micro-business Skills, operational skills and other content were explained in detail. The training combines the theory with the actual operation of e-commerce, so that the participants can master the professional skills of shop opening process, product release, online store operation, promotion and promotion. And help them establish Internet thinking, expand sales channels, and provide power for the development of Huinan's e-commerce industry.

The 2nd Jilin Province Young Rural Electric Merchants Training Camp and the "Volcano Jilin Fortune Partners" Hundred People Plan and the "100 County Thousands of Goods" Jilin Project are the implementation of the Communist Youth League's Jilin Provincial Committee to help the poor and strengthen the young rural electric merchants. The important measures are to select and produce 100 short-lived videos from 35 outstanding new media practitioners in 39 counties across the province, empower regional economic development and urban cultural propaganda, open a micro-shop, and mine high-quality agricultural products in Jilin. Effectively help farmers increase their incomes.

\section{THE DILEMMA FACED BY THE DEVELOPMENT OF YOUTH E-COMMERCE IN JILIN PROVINCE}

\section{A. Starting Relatively Late}

The start of youth e-commerce in Jilin Province was relatively late compared to other provinces. Due to the geographical location of Jilin Province, e-commerce started later than other coastal cities. In 2013, there were 2 Taobao Villages in Fujian, 28 in 2014, 71 in 2015, and Taobao Town 
and cross-border e-commerce exports exceeded 3 billion yuan. By 2025, the province's e-commerce industry system has been basically completed, which has formed a strong support for the sustainable development of the province's economy. The e-commerce transaction volume reached 2 trillion yuan, the online retail sales exceeded 120 billion yuan, and the agricultural product network sales exceeded 50 billion yuan. The cross-border e-commerce exports exceeded 6 billion yuan. The deep integration of e-commerce and the first, second and third industries has led to a significant increase in new mobilizations such as new retail, new consumption, new trade, new formats, new models and new platforms. Digital commerce, digital consumption, digital trading and digital service capabilities have significantly improved. . In order to achieve the goal, we will further improve the youth e-commerce entrepreneurship support policy, and provide relevant tax reductions or financial subsidies and other preferential policies for relevant youth entrepreneurship service institutions, youth entrepreneurship internships and training bases. Further improve the incentives and subsidy standards for youth entrepreneurship, appropriately reduce the scope of subsidies, and really give strong support to those who want to start a business and start a business, truly support a family to stabilize one household, effectively improve entrepreneurs to declare various rewards, The enthusiasm of subsidies. We will increase the publicity and implementation of existing youth entrepreneurship support policies, compile and publish special entrepreneurship policy brochures, and distribute publicity through various channels to enable more entrepreneurial youth to know and be able to enjoy relevant support policies.

\section{B. Youth E-commerce Financing Services}

The existing small-guarantee loans for entrepreneurship are tilted to e-commerce, encourage the establishment of various e-commerce venture funds, and increase support for youth e-commerce projects. Encourage e-commerce financial funds to cooperate with social capital and financial capital, create an e-commerce guarantee fund, and launch exclusive products for e-commerce finance. Strengthen cooperation between the government and platforms and financial enterprises, promote the construction of a youth ecommerce credit system, and reduce the cost and risk of ecommerce financing. It is also possible to set up a youth entrepreneurship financing platform and a guarantee platform, and cooperate with financial institutions such as banks to set up special funds and other financing services for young e-commerce companies. For the purpose of paid use or risk sharing and benefit sharing, high-quality and promising Entrepreneurship projects support and promote youth entrepreneurship to high-end development.

\section{Strengthening the Cultivation of Electric Merchants}

It is necessary to adhere to the combination of college education and off-campus training, support the talent demand for rural e-commerce development, and improve the cultivation system for returning rural youth e-commerce entrepreneurship. For business leaders, college students, university student village officials, rural cooperatives, returning youths and interested individuals who are engaged 
in e-commerce entrepreneurship to conduct rural ecommerce practical training classes, college students village e-commerce training courses, e-commerce primary training courses, e-commerce training courses and other short-term ecommerce training courses. Implement the e-commerce entrepreneurship training certification system, and use ecommerce training certification as an important basis for entrepreneurial youth to enjoy policy support and entrepreneurial services. Adhere to the principle of classified training, adopt flexible training and education forms such as on-demand training and menu selection, improve the pertinence and effectiveness of e-commerce entrepreneurship training, and truly improve the skills of youth e-commerce entrepreneurship.

\section{CONCLUSION}

The Communist Youth League should consolidate various forces, starting from building platforms, increasing support, and purchasing services, to effectively provide better and more efficient services and guidance, and provide strong support for youth innovation and entrepreneurship.

\section{ACKNOWLEDGMENT}

This work was financially supported by Jilin Provincial Committee of the Communist Youth League of China, Project number : 2019jqy-013.This work was financially supported by School-level scientific research projects of JiLin Engineering Normal University, Project number: XYB201832; Supported by Science and Technology Department of Jilin Province soft science project funding, Project number: 20190601075FG.

\section{REFERENCES}

[1] Implementation Plan for the Construction of Jilin Province Grassroots Service Group (Jiqing Home) [Z/OL]. http://www.j154.org/jlgqt/public/no_List.jsp?classid=1216000000\&m ainid $=1216000000$.

[2] Wang Xiangdong, Liang Chunxiao. "New Sannong" and Ecommerce [M]. China Agricultural Science and Technology Press, 2014.

[3] Huang Qiongying. Exploring the "Order-Oriented" Training of Applied Talent Model in Logistics Management Specialty[J]. Theoretical Research, 2013(6).

[4] Wei Yanan, China's e-commerce poverty alleviation review and prospects, "Agricultural Network Information", 2017, No. 9, 16-22.

[5] Statistics of Jilin Provincial Department of Commerce website http://swt.jl.gov.cn/zfxxgk/ 